\title{
CARBON ISOTOPE DISTRIBUTION ALONG PINE NEEDLES (PINUS NIGRA ARNOLD)
}

\author{
LIDIA BARSZCZOWSKA ${ }^{1}$, MARIUSZ-ORION JĘDRYSEK \\ Laboratory of Isotope Geoecology, University of Wrocław \\ Cybulskiego 30, 50-205 Wrocław, Poland \\ 1 e-mail: khandro@ing.uni.wroc.pl
}

(Received: September 9, 2004. Accepted: November 10, 2004)

\begin{abstract}
In this paper we show spatial carbon isotope variations in black pine (Pinus nigra Arnold) needles, collected in spring 2001 and autumn 2003, from trees at the coast of south-western Croatia island (Žirje) and southern Spain (Benalmadena near Malaga), respectively. Needles were segmented perpendicularly to the longer axis (base, middle and top) and each segment was analysed separately. $\delta^{13} \mathrm{C}$ values in needles from Croatia varied between $-26.65 \%$ to $-24.43 \%$ ( 2 months old needles) and from $-28.25 \%$ to $-25.21 \%$ ( 1 year old needles), while $\delta^{13} \mathrm{C}$ values in needles from Spain varied from $-27.58 \%$ o to $-25.27 \%$. The difference between $\delta^{13} \mathrm{C}_{\mathrm{b}}$ (base) and $\delta^{13} \mathrm{C}_{\mathrm{t}}$ (top) in the same needle $\left(\Delta^{13} \mathrm{C}_{\mathrm{b}-\mathrm{t}}\right)$ varied from 1.85 to $2.05 \%$ (in young needles from Croatia), from 0,02 to $1,80 \%$ o (young needles from Spain), and 1.16 to $2.32 \%$, (in old needles from Croatia). The average $\Delta^{13} \mathrm{C}_{\mathrm{b}-\mathrm{t}}$ values were $0.78 \%$ and $1.73 \%$ in Spain and Croatia, respectively. In each needle the base of the needle was always ${ }^{13} \mathrm{C}$-enriched as compared to the top of the same needle. This evidences that carbon isotopes are not retranslocated after its fixation into the leaf structure (after the growth process is over). Temperature variation was most probably negligible for the discovered intraneedle carbon isotope distribution. Although, the intraneedle carbon isotope inhomogeneity can be partly the result of seasonal variation in $\delta^{13} \mathrm{C}$ of atmospheric $\mathrm{CO}_{2}$, most probably the remarkably high $\Delta^{13} \mathrm{C}_{\mathrm{b}-\mathrm{t}}$ values, and regular pattern, are predominantly resulting from isotopic and chemical composition of primary and secondary products contained in the growing part of needle and kinetic isotope fractionation during decomposition of storage materials at the base.
\end{abstract}

KEY WORDS: needle, growth, pine, Pinus nigra, carbon isotopes, kinetic isotope effects, inhomogeneity.

\section{INTRODUCTION}

Historically, isotopes have played an important role in earth sciences (studying origin of oil and ore deposits, climatic changes etc.) and as diagnostic tools for assessing anthropogenic impact on natural environment. Recently, isotope analyses are widely used in plant studies and human modified experiments throughout a wide range of biological studies. Radiogenic ${ }^{14} \mathrm{C}$-isotopic analyses allow to evaluate the age of subfossil biological materials (e.g. trees) and to follow metabolic processes, while short term changes in key plant physiological parameters (such as stomatal conductance, carbon exchange rates and phloem transport of carbon in shoots and roots) can be assessed using the short-lived gamma-emitting isotope ${ }^{11} \mathrm{C}$. Stable isotope analyses of ${ }^{13} \mathrm{C} /{ }^{12} \mathrm{C}$ ratio in recent plants can help better understanding of mechanisms of assimilation and dynamics of the plant growth and it is a standard method to distinguish between $\mathrm{C}_{4}$ and $\mathrm{C}_{3}$ plants (e.g. O'Leary 1981, 1995; Leavitt and Long 1986; Farquhar et al. 1989; Cole- man and Fry 1991; Schleser 1991; Robertson et al. 1997; Hemming et al. 1998; Jędrysek et al. 2003).

Although our data are similar to those on stable carbon isotope variations in single tree foliage obtained by other authors (Leavitt and Long 1982, 1986; Hanba et al. 1997; Schleser 1999), our results refer to segmented needles. The main objective of this study was to determine homogeneity of $\mathrm{C}$ isotope composition in single needles of pine trees. This was done to better understand the mechanisms of carbon isotope fractionation in the atmospheric $\mathrm{CO}_{2}$-plant system being the most important element of $\mathrm{C}$ cycling on earth and a crucial step to calibrate the isotopic tool for paleoenvironmental reconstructions.

\section{MATERIALS AND METHODS}

Needles samples from single stands of pine Pinus nigra from Croatia (Žirje Island; N 4400', E 17³0', 40 m altitude a.s.1.) and southern Spain (Benalmadena near Malaga; 


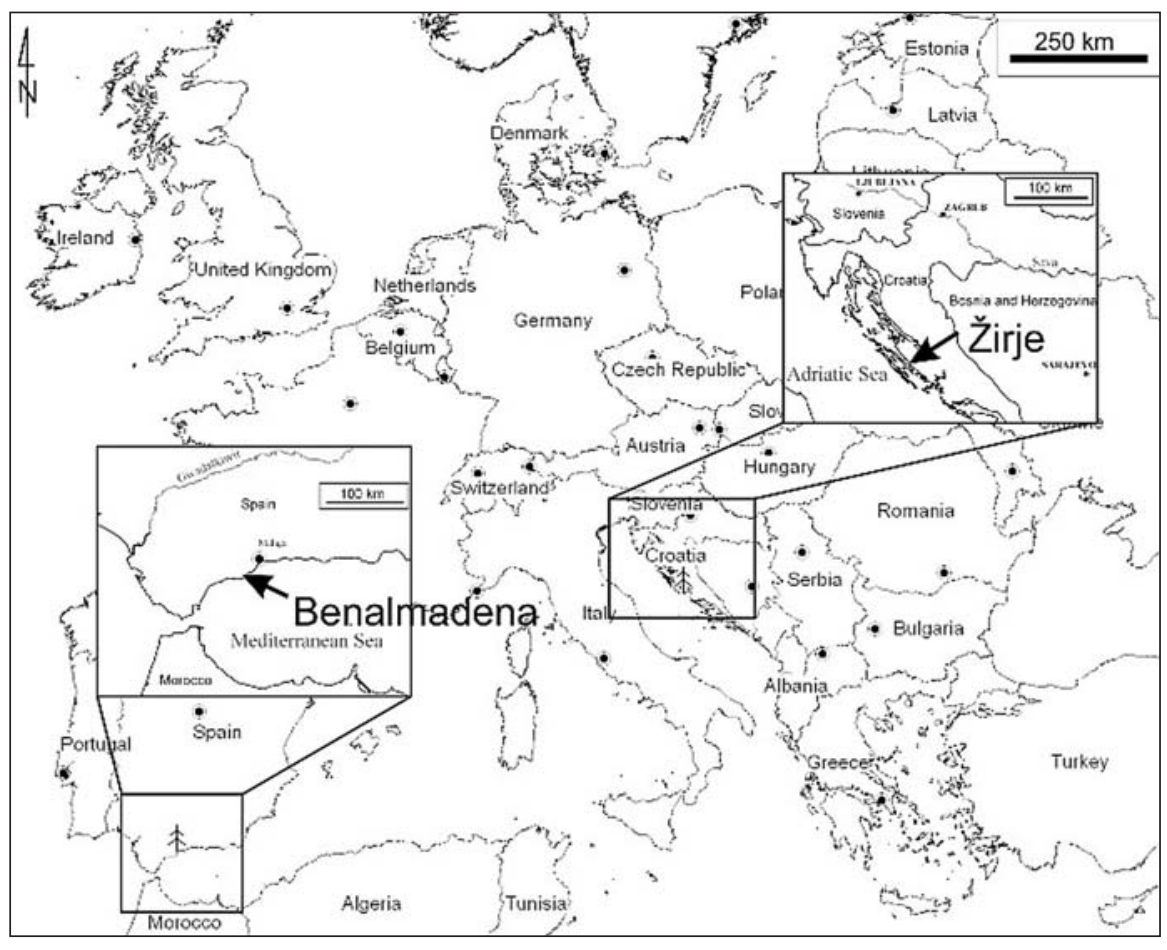

Fig. 1. Schematic map showing location of sampling sites.
N 36 $58^{\prime}$, W 4 ${ }^{\circ} 58^{\prime}, 200 \mathrm{~m}$ altitude a.s.1.) were collected on 22nd of May 2001 and on 5th of October 2003, respectively (Fig. 1). Young needles (about 2-3 and 7 months old) and old needles ( 1 and 2 years old) have been selected for carbon isotope analyses. The needles were cut, (perpendicularly to the longer axis) into three segments (sections) the base, middle and the top (see Fig. 2, Table 1 and 2). Needles Zr 1.3 and Zr 1.4 from Croatia (Fig. 2, Table 2) were segmented into halves (two parts only) thus the results are not well comparable to all the other needles always segmented into three parts.

About 1-3 mg of each sample was combusted with $\mathrm{CuO}$ wire in a sealed quartz tube, under vacuum at $900^{\circ} \mathrm{C}$. The obtained $\mathrm{CO}_{2}$ gas was cryogenically purified using liquid nitrogen and dry-ice ethanol mixture. The $\mathrm{CO}_{2}$ was introduced to mass spectrometer Finnigan-Mat Delta E (in La-

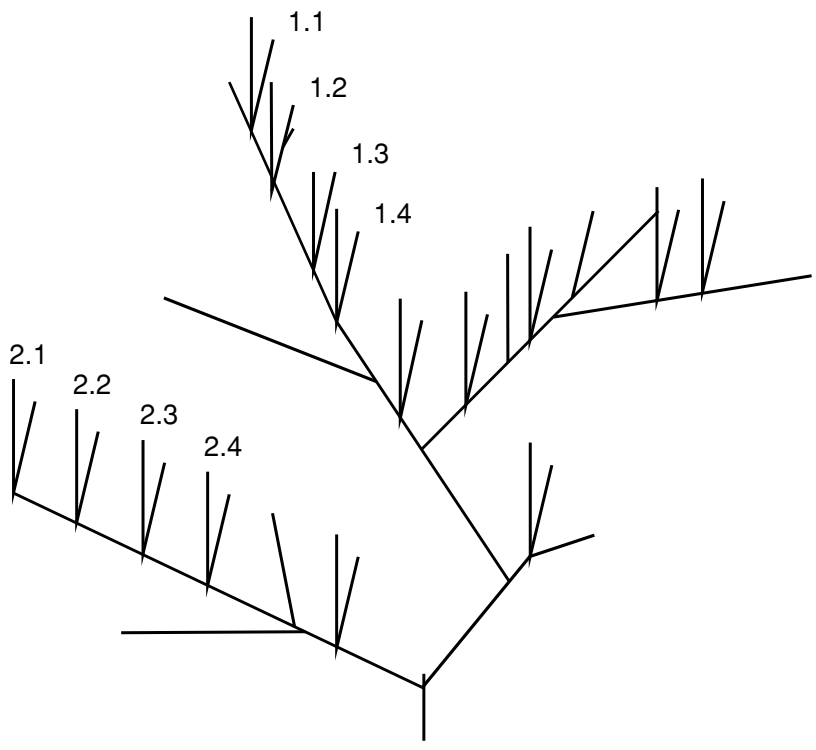

Fig. 2. Scheme showing the system of needle selection for $\mathrm{C}$ isotope analysis. The numeral labels corresponds to sample names (see Tables 1 and 2). boratory of Isotope Geoecology, University of Wroclaw) for isotopic ratio analyses. The obtained results are shown as $\delta$ (delta) value quoted relative to the Pee Dee Belemnite international standard, with precision $0.05 \%$ and reproductibility ca. $0.5 \%$. The $\delta$ value is defined:

$$
\delta^{13} \mathrm{C}=\left[\left(\mathrm{R}_{\text {sample }}-\mathrm{R}_{\text {standard }}\right) / \mathrm{R}_{\text {standard }}\right] \times 1000 \% \text { o }
$$

where $\mathrm{R}$ is the ratio between ${ }^{13} \mathrm{C}$ and ${ }^{12} \mathrm{C}$ in sample and standard.

\section{RESULTS}

The $\delta^{13} \mathrm{C}$ value in needles from Croatia and Spain varied from $-28.25 \%$ o to $-24.43 \%$ and from $-27.58 \%$ to $-25.27 \%$, respectively (Tables 1 and 2). The difference in $\delta^{13} \mathrm{C}$ values between the base $\delta^{13} \mathrm{C}_{\mathrm{b}}$ and the top and $\delta^{13} \mathrm{C}_{\mathrm{t}}$ of a single needle $\left(\Delta^{13} \mathrm{C}_{\mathrm{b}-\mathrm{t}}\right)$ varied from $0.02 \%$ (Spain, B 2.3, Table 1 , young needle) to $2.32 \%$, (Croatia, $\mathrm{Zr} 2.3$, Table 2, old needle). The average $\Delta^{13} \mathrm{C}_{\mathrm{b}-\mathrm{t}}$ values of all needles varied from $0.78 \%$ and $1.73 \%$ in Spain and Croatia, respectively (Tables 1 and 2).

The $\Delta^{13} \mathrm{C}_{\mathrm{b}-\mathrm{t}}$ value in young needles from Croatia varied from 1.85 to $2.05 \%$, with an average $1.95 \%$, while $\Delta^{13} \mathrm{C}_{\mathrm{b}-\mathrm{t}}$ in older needles varied from $1.16 \%$ to $2.32 \%$, with an average of $1.51 \%$ (Table 2). Therefore, in general, older needles show higher $\Delta^{13} \mathrm{C}_{\mathrm{b}-\mathrm{t}}$ values than younger ones (Table 2, Fig. 3).

\section{DISCUSSION}

\section{Whole needles - growing conditions}

As atmospheric carbon dioxide is the only source of carbon for plants, $\delta^{13} \mathrm{C}$ in plants is controlled by $\delta^{13} \mathrm{C}$ of $\mathrm{CO}_{2}$ and isotope fractionation during assimilation. Atmospheric $\delta^{13} \mathrm{C}\left(\mathrm{CO}_{2}\right)$, due to buffering by the global ocean, is rather stable throughout the time, (see e.g. Freidli et al. 1986; 
TABLE $1 . \delta^{13} \mathrm{C}$ values in needles from Spain about 7 moths old needles. All needles in both series sampled on 5 th of October 2003.

\begin{tabular}{|c|c|c|c|c|c|}
\hline Spain & & ic comp & & Whole needle & Difference $[\% o]$ \\
\hline Sample name & $\delta^{13} \mathrm{C}_{\mathrm{t}}$ & $\delta^{13} \mathrm{C}_{\mathrm{m}}$ & $\delta^{13} \mathrm{C}_{\mathrm{b}}$ & Average & $\Delta^{13} \mathrm{C}_{\text {b-t }}$ \\
\hline В 1.1 & -27.58 & -26.57 & -25.78 & -26.64 & 1.80 \\
\hline B 1.2 & -27.21 & -26.38 & -26.56 & -26.72 & 0.65 \\
\hline B 1.3 & -26.17 & -25.89 & -25.86 & -26.64 & 0.31 \\
\hline В 1.4 & -26.94 & -26.48 & -26.41 & -26.72 & 0.53 \\
\hline Average & -26.97 & -26.33 & -26.15 & -26.68 & 0.82 \\
\hline B 2.1 & -26.88 & -26.03 & -25.27 & -26.49 & 1.61 \\
\hline B 2.2 & -26.85 & -25.70 & -26.04 & -26.20 & 0.81 \\
\hline B 2.3 & -25.83 & -26.23 & -25.81 & -26.06 & 0.02 \\
\hline В 2.4 & -26.62 & -26.41 & -26.13 & -26.20 & 0.49 \\
\hline Average & -26.55 & -26.09 & -25.81 & -26.23 & 0.73 \\
\hline Average of all & -26.62 & -26.13 & -25.87 & X & 0.78 \\
\hline
\end{tabular}

B - Benalmadena (Spain); $\mathrm{t}$ - top; $\mathrm{m}$ - middle; $\mathrm{b}$ - base; $\mathrm{X}$ - not relevant

TABLE 2. $\delta^{13} \mathrm{C}$ values obtained for each needle from Croatia. Needles Zr 1.1 to Zr 1.4 are up to 3 months old needles, sampled on $22^{\text {nd }}$ of May 2001. Needles $\mathrm{Zr} 2.1$ to $\mathrm{Zr} 2.4$ are more than a year old needles, sampled on $22^{\text {nd }}$ of May 2001.

\begin{tabular}{|c|c|c|c|c|c|}
\hline Croatia & & ic comp & & Whole needle & Difference $[\% o]$ \\
\hline Sample name & $\delta^{13} \mathrm{C}_{\mathrm{t}}$ & $\delta^{13} \mathrm{C}_{\mathrm{m}}$ & $\delta^{13} \mathrm{C}_{\mathrm{b}}$ & Average & $\Delta^{13} \mathrm{C}_{\mathrm{b}-\mathrm{t}}$ \\
\hline Zr 1.1 & -26.65 & -26.52 & -24.80 & -25.99 & 1.85 \\
\hline $\mathrm{Zr} 1.2$ & -26.48 & -26.13 & -24.43 & -25.68 & 2.05 \\
\hline Zr 1.3 & -26.26 & n.a. & -26.02 & -26.14 & 0.24 \\
\hline Zr 1.4 & -25.99 & n.a. & -25.06 & -25.53 & 0.93 \\
\hline Average & -26.35 & -26.33 & -25.08 & -25.83 & $1.95 *$ \\
\hline $\mathrm{Zr} 2.1$ & -28.25 & -27.53 & -26.97 & -27.58 & 1.28 \\
\hline $\mathrm{Zr} 2.2$ & -27.76 & -26.05 & -26.60 & -26.80 & 1.16 \\
\hline Zr 2.3 & -27.53 & -26.97 & -25.21 & -26.57 & 2.32 \\
\hline Zr 2.4 & -26.99 & -27.08 & -25.70 & -26.59 & 1.29 \\
\hline Average & -27.63 & -26.91 & -26.12 & -26.89 & 1.51 \\
\hline Average of all & 26.56 & -26.47 & -25.25 & X & $1.73 *$ \\
\hline
\end{tabular}

$\mathrm{Zr}$ - Žirje (Croatia); $\mathrm{t}$ - top; $\mathrm{m}$ - middle; $\mathrm{b}$ - base; $\mathrm{X}$ - not relevant

n.a. - not analyzed because samples $\mathrm{Zr} 1.3$ and $\mathrm{Zr} 1.4$ were segmented into halves (two parts only) - thus, the results are not well comparable to all the other needles always segmented into three parts.

* the average value do not represent samples $\mathrm{Zr} 1.3$ and $\mathrm{Zr} 1.4$.

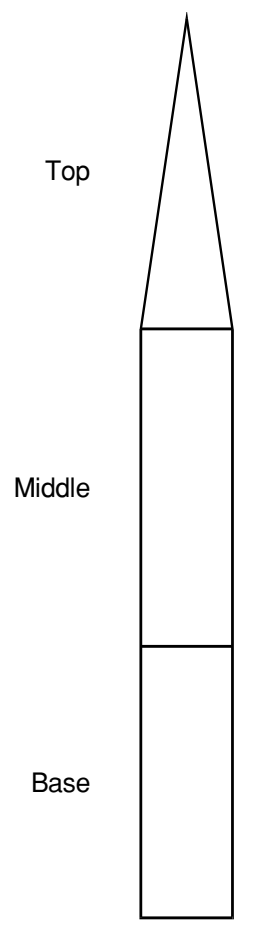

Fig. 3. Scheme showing the segmentation of needle for $\mathrm{C}$ isotope analysis.
Szaran 1990; Keeling and Whorf 1996; Levin et al. 1996). Therefore, fractionation during assimilation is rather crucial. In general, the carbon isotope fractionation between atmospheric $\mathrm{CO}_{2}$ and assimilates is the combined result of an enzymatic (RUBISCO) carbon isotope fixation effect, which may be about $-27 \%$, and a diffusion isotope effect that may result in a $-4.4 \%$ isotope fractionation. This interaction in higher plants is complex and discussed by many authors (e.g. Farquhar et al. 1989; Robertson et al. 1997; Hemming et al. 1998). The overall difference between the isotopically lightest $\left(\delta^{13} \mathrm{C}=-28.25 \%\right.$ ) and isotopically heaviest $\left(\delta^{13} \mathrm{C}=-24.43 \%\right)$ parts of different needles of the same tree from Croatia reached $\Delta^{13} \mathrm{C}=4.22 \%$ o (with an average of $1.73 \%$ ), while, regardless the age class of needles, in Spain the $\Delta^{13} \mathrm{C}$ value was up to $2.31 \%$ (with an average of $0.78 \%$ ) and $\delta^{13} \mathrm{C}$ varied from $-27.58 \%$ to $-25.27 \%$. We suggest that variation in humidity and isotopic equilibrium of atmospheric $\mathrm{CO}_{2}$ with oceanic DIC (Dissolved Inorganic Carbon) was the main driving mechanism of the difference in the $\Delta^{13} \mathrm{C}$ between the Croatian and Spanish needles. Namely, humidity has been noted as a key climatic parameter that can influence leaf gas exchange (ventilation) rate, through its effect on stomatal aperture (see e.g. Farquhar et al. 1989; Saurer and Siegen- 

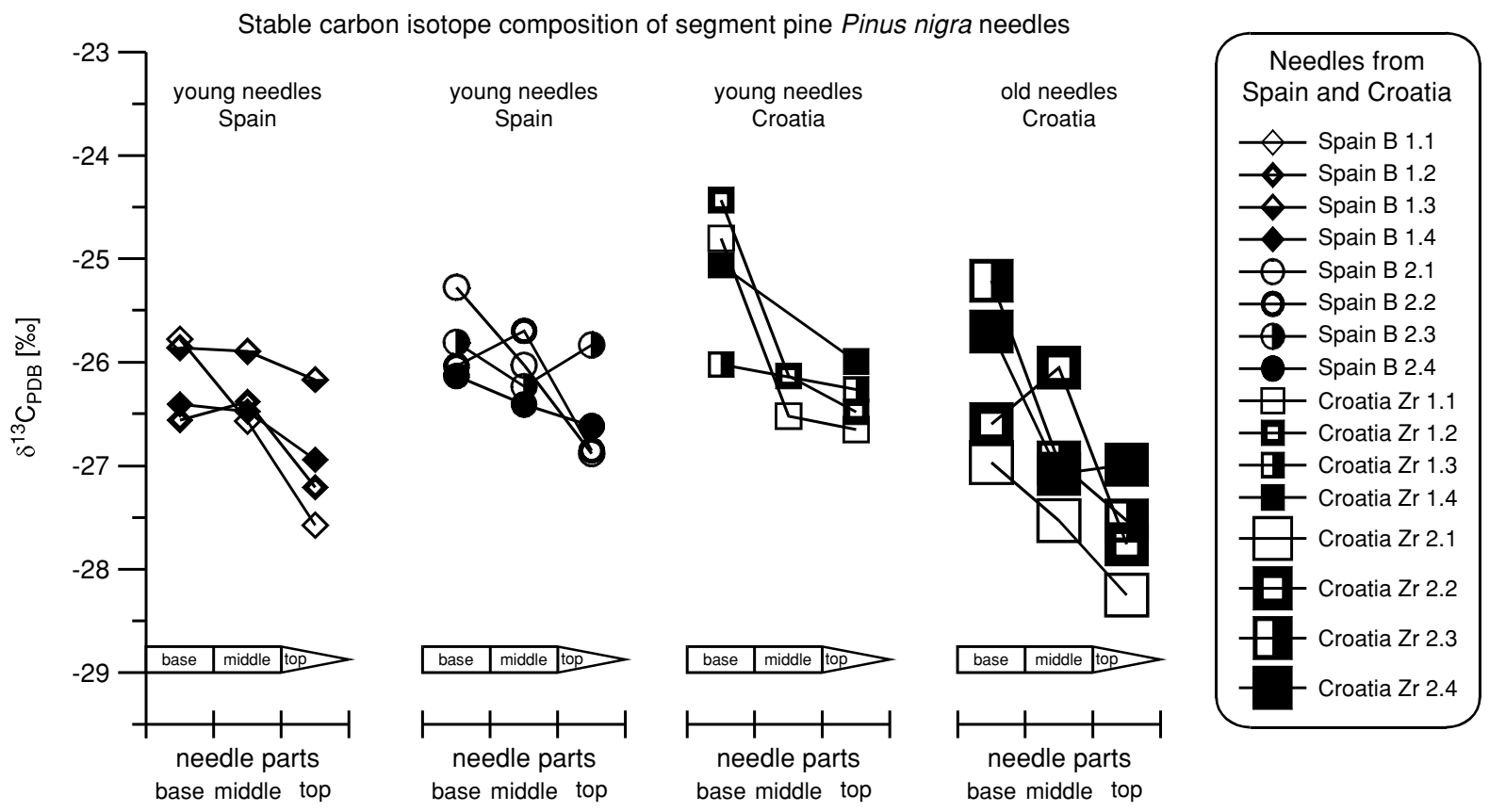

Fig. 4. Stable carbon isotope composition of different segmented needles of Pinus nigra. Needles were collected in Spain and Croatia (see Fig. 1 and Materials and Methods). Samples $\mathrm{Zr} 1.3$ and $\mathrm{Zr} 1.4$ were segmented into halves (two parts only) thus the results are not well comparable to all the other needles always segmented into three parts.

thaler 1989) and recent calibration of $\delta^{13} \mathrm{C}$-temperature and $\delta^{13} \mathrm{C}$-precipitation clearly shows that water abundancy controls C-isotope ratios in trees (Jędrysek et al. 2003). It can be accepted that the Croatian needles have grown at unstable conditions with respect to humidity and $\delta^{13} \mathrm{C}$ of atmospheric $\mathrm{CO}_{2}$, because the sampled tree was on a small island distant ca. $5 \mathrm{~km}$ from the continent very close to the ocean (ca. $40 \mathrm{~m}$ a.s.l). In calm conditions or winds from the ocean the plant-atmosphere carbon isotope fractionation system was totally controlled by the ocean, while during continental winds the air was dry and at isotopic disequillibrium with the oceanic DIC. Therefore, any change in the direction of the wind dramatically changed these two parameters which are crucial for isotope ratios in plants. The Spanish needles were taken from a tree growing about $1 \mathrm{~km}$ from the seaside and about $200 \mathrm{~m}$ above sea level. The higher altitude and larger distance from the ocean suppressed the role of the ocean thus, humidity of the air and isotope composition of atmospheric $\mathrm{CO}_{2}$ were probably much less controlled by direction of winds, thus less variable. The role of atmospheric pollutions can be ignored as all needles were sampled in rather pristine environment and only dramatic atmospheric pollutions can move $\delta^{13} \mathrm{C}$ to more positive values by about $1.3 \%$ (Jędrysek et al. 2003)

\section{Whole needles - age classes}

Here we demonstrate age trends i.e. the younger the needle, the higher ${ }^{13} \mathrm{C} /{ }^{12} \mathrm{C}$ isotope ratios are observed (Fig. 3). Possibly, differences in dynamics of photosynthesis and in the structure of photosynthetic organs (K. Bielecki - personal communication) cause this trend. Likewise, younger leaves have lower contents of compounds responsible for carbon fixation (chlorophyll and carotenoids) as compared to the older ones (Oleksyn 1998). We postulate that efficient assimilation by less developed stomatas during fast grow of younger needles results in an enhanced kinetic iso- tope effect, hence the higher $\delta^{13} \mathrm{C}$ value, because the rate between ventilation and fixation of carbon can be higher in younger needles and ${ }^{13} \mathrm{C}$ is assimilated from a limited $\mathrm{CO}_{2}$ dynamic pool.

\section{Segmented needles}

The question concerning the mechanism of carbon isotope fractionation within a single leaf growth remains unanswered. The base part of the needle is always enriched in ${ }^{13} \mathrm{C}$-isotope as compared to the top of the same needle, and the middle of the same needle shows usually a middle range of $\delta^{13} \mathrm{C}$ value in the same leaf (Fig. 3). This can be caused by the mechanism of needle growth. Namely, because the base shows intercostal growth (Hejnowicz 2002) it can be suggested that needles grow at the base, so this part of the needle is the youngest. Consequently, the top of the needle is the oldest one. However, in some cases the middle part of the needle is isotopically heavier or lighter than its base or top, respectively (Fig. 3). Therefore, some other processes may also influence the intraneedle spatial $\delta^{13} \mathrm{C}$ -inhomogeneity.

Keep in mind that the intraneedle spatial inhomogeneity occurs in all needles analyzed, regardless the age class (2-3-months, about 7 months old needles and in the older ones, 1 or 2-year-old needles) and season and place - needles collected at the beginning of vegetation season (in May) show the same trend in $\delta^{13} \mathrm{C}$ value as needles sampled at the end of vegetation season (October). Therefore, the $\delta^{13} \mathrm{C}$ trend can not be the result of seasonal variation in $\delta^{13} \mathrm{C}$ value of atmospheric $\mathrm{CO}_{2}$ which shows a small increase during the vegetation period and a reverse trend during winter. The older part of needles (spring growth) should show lower $\delta^{13} \mathrm{C}$ value as compared to the younger part of the needle (summer and autumn growth). This corresponds to our results, but at the area close to the ocean this effect should be smaller due to the dominating role of the oceanic 
DIC. The Croatian needles show the largest $\Delta^{13} \mathrm{C}_{\mathrm{b}-\mathrm{t}}$ value, while it should be expected to be small, due to the buffering role of the ocean. On the other hand, differences in carbon isotope composition between the base and the top $\left(\Delta^{13} C_{b-t}\right)$ are slightly smaller in younger needles $(0.78 \%$ in Spain and $1.95 \%$ in Croatia) than in the older ones $(1.51 \%$ in Croatia). This can be regarded to the short time of growth, when seasonal changes in the atmospheric $\delta^{13} \mathrm{C}$ are small, but it is doubtful to have more than $1 \%$ increase in $\delta^{13} \mathrm{C}\left(\mathrm{CO}_{2}\right)$ value in several weeks when the young needles were growing, showing $\delta \Delta^{13} \mathrm{C}_{\mathrm{b}-\mathrm{t}}=1.95 \%$. Those results may suggest that temperature variations or other seasonal changes do not control the intraneedle carbon isotope distribution and carbon isotopes are not retranslocated after fixation into the structure when needle is not growing anymore (when the process of growth is over). Moreover, the smaller spatial C-isotope inhomogenity of needles from Spain results probably from smaller variation of air humidity and $\delta^{13} \mathrm{C}$ of assimilated $\mathrm{CO}_{2}$ at the growing site.

Intercostal tissue, which is placed in the needle base, contains some compounds of storage tissue and primary products in needles. According to Schleser (1999) intercostal tissue from different places of a leaf does not show different $\delta^{13} \mathrm{C}$ values. The same author (Schleser 1991) suggests that intercostal tissue is isotopically lighter than the other tissues (except the initial parts of stem), such as leaf lamina, ribs and petiole. Although this authors' data concern leaves of deciduous trees, different in their construction from conifers, some basic information could be helpful in determining the origin of the $\delta^{13} \mathrm{C}$-inhomogeneity observed. Unfortunately, the apparent intercostal tissue analysed by Schlesser (1991) was not strictly intercostal tissue, but rather an assemblage of several other tissues present in the beech (Fagus silvatica) leaf studied. Therefore, the data of that author are not directly applicable to our data.

It is well known that chemical composition of primary and secondary products contained in the needle tissue varies with time and age of needles. The primary products in $\mathrm{C}_{3}$ plants are usually isotopically heavier in carbon, than the secondary ones, e.g. carbohydrates (such as sucrose or starch) are enriched in $\delta^{13} \mathrm{C}$ as compared to cellulose and especially lignin and lipids, which are isotopically the lightest (Farquhar et al. 1989; Gleixner et al. 1993; O'Leary 1981, 1995; Van de Water 2002). Likewise, storage tissues (e.g. roots and seeds) are isotopically heavier than the remaining tissues (Farquhar et al. 1989; O'Leary 1995; Gleixner et al. 1993). The young base of needle might contain some primary or storage products. When growing needles use storage material (e.g. starch) and ${ }^{12} \mathrm{C}$ isotopes are actively incorporated into the new tissue, the remaining storage material enriches in ${ }^{13} \mathrm{C}$ isotope. Consequently, the older parts of needles are ${ }^{13} \mathrm{C}$-depleted (isotopically lighter) as compared to the younger part at the base which are found to be ${ }^{13} \mathrm{C}$-enriched. This model avoids, what is hard to accept, reequilibration or retranslocation of ${ }^{13} \mathrm{C}$ isotopes.

\section{CONCLUSIONS}

1. Needles grow at the base, so this part of the needle is the youngest. Consequently, the top of the needle is the oldest one.
2. Differences between the base and the top $\left(\Delta^{13} \mathrm{C}_{\mathrm{b}-\mathrm{t}}\right)$ of a single pine needle (within segmented needles of Pinus nigra) varied from $0.02 \%$ to $2.32 \%$. Average $\Delta \Delta^{13} \mathrm{C}_{\mathrm{b}-\mathrm{t}}$ values were $0.78 \%$ and $1.75 \%$ in Spain and Croatia, respectively. The base of a needle is always ${ }^{13} \mathrm{C}$-enriched with respect to the top of the needle. Likewise, in general the middle of the needle shows usually medium isotope values.

3. Intraneedle spatial inhomogeneity occurs in all needles analysed, regardless age class and season - needles collected at the beginning of vegetation season (in May) show the same trend in $\delta^{13} \mathrm{C}$ value as needles sampled at the end of vegetation season (October).

4. Temperature variation is not the governing factor for the intraneedle distribution of carbon isotopes

5. Carbon isotopes are not retranslocated after fixation into the structure of the needle (when the growth process is over).

6. Although, the intraneedle carbon isotope inhomogeneity can partly resulted from seasonal variation in the $\delta^{13} \mathrm{C}$ of atmospheric $\mathrm{CO}_{2}$, most probably the remarkably high $\Delta \Delta^{13} \mathrm{C}_{\mathrm{b}-\mathrm{t}}$ values, and regular pattern, are dominantly caused by isotopic and chemical composition of primary and secondary products contained in the growing part of a needle and kinetic isotope fractionation during decomposition of storage materials at the base.

7. Smaller spatial C-isotope inhomogenity of needles from Spain results probably from smaller temporal variation in: (i) the air humidity and, (ii) $\delta^{13} \mathrm{C}$ of assimilated $\mathrm{CO}_{2}$ at the growing site.

\section{ACKNOWLEDGEMENTS}

The authors are very grateful to dr Bronislaw Wojtuń and dr Krzysztof Bielecki for invaluable discussions on plant physiology, helpful suggestions and critical comments. This study has been supported from "S" 1017/S/ING/04-IX and "W" 2022/W/ING/02-12 grants at the University of Wrocław, and IAI.

\section{LITERATURE CITED}

COLEMAN D.C., FRY B. 1991. Carbon isotope techniques. In: Isotopic Techniques in Plant, Soil, and Aquatic Biology. Academic Presss, INC. pp. 1-274.

FARQUHAR G.D., EHLERINGER J.R., HUBICK K.T. 1989. Carbon isotope discrimination and photosynthesis. Annu. Rev. Plant Physiol. Plant Mol. Biol. 40: 503-537.

FREIDLI H., LÖTSCHER H., OESCHGER H., SEIGENTHALER U., STAUFFER B. 1986. Ice core record of the ${ }^{13} \mathrm{C} /{ }^{12} \mathrm{C}$ ratio of atmospheric $\mathrm{CO}_{2}$ in the past two centuries. Nature, 324, 237-328.

GLEIXNER G., DANIER H.-J., WERNER R.A., SCHMIDT H.L. 1993. Correlations between the ${ }^{13} \mathrm{C}$ content of primary and secondary plant products in different cell compartments and that in decomposing Basidiomycetes. Plant Physilogy 102: 1287-1290.

HANBA Y.T., MORI S., LEI T.T., KOIKE T., WADA E. 1997. Variations in leaf $\delta^{13} \mathrm{C}$ along a vertical profile of irradiance in a temperate Japanese forest. Oecologia 110: 253-261, Springer-Verlag.

HEJNOWICZ Z. 2002. Anatomia i histogeneza roślin naczyniowych - Organy wegetatywne. PWN, Warszawa, pp. 1-980. (in Polish) 
HEMMING D.L., SWITSUR V.R., WATERHOUSE J.S., HEATON T.H.E., CARTER A.H.C. 1998. Climate variation and the stable isotope composition of tree ring cellulose: an intercomparison of Quercus robur, Fagus silvatica and Pinus sylvestris. Tellus, 50B (1): 25-33.

JĘDRYSEK M.O., KRAPPIEC M., SKRZYPEK G., KAŁUŻNY A. 2003. Air-pollution effect and Paleotemperature Scale versus $\delta^{13} \mathrm{C}$ Records in Tree Rings and in a Peat Core (Southern Poland). Water, Air and Soil Pollution, 145, 359-375.

KEELING C.D., WHORF T.P. 1996. Atmospheric $\mathrm{CO}_{2}$ records from sites in the SIO air sampling network. In: Trends: A compendium of data on global change. Carbon Dioxide Information Analysis Centre, Oak Ridge National Laboratory, Oak Ridge, Tenn., USA.

LEAVITT S.W., LONG A. 1982, Evidence for ${ }^{13} \mathrm{C} /{ }^{12} \mathrm{C}$ fractionation between tree leaves and wood. Nature, Vol. 298, $19 \mathrm{Au}-$ gust 1982.

LEAVITT S.W., LONG A. 1986. Stable-carbon isotope variability in tree foliage and wood. Ecology, 67 (4), 1986, pp. 1002$-1010$.

LEVIN I., KROMER B., SCHOCH-FISCHER H., BRUNS M., MÜNNICH M., BEDRAU D., VOGEL J.C., MÜNNICH K. 1996. $\delta^{13} \mathrm{C}$ records from sites in Central Europe. In: Trends' 93 : A compendium of data on global change, (eds) T.A. Boden, D.P. Kaiser, R.J. Stepanski, F.W. Stoss. ORNL/CDIAC-65., Carbon Dioxide Information Analysis Centre, Oak Ridge National Laboratory, Oak ridge, Tenn., USA.

O'LEARY M.H. 1981. Carbon isotope fractionation in plants, Phytochemistry, Vol. 20, No. 4, pp. 553-567.
O'LEARY M.H. 1995. Environmental effects on carbon isotope fractionation in terrestial plants. In: Stable isotopes in the biosphere, (ed.) Wada E., Yoneyama T., Minagawa M, Ando T., Fry B.D., Kyoto University Press, pp. 78-89.

OLEKSYN J. 1998. Wymiana gazowa i gospodarka wodna, In: Biologia świerka pospolitego, Podstawy fizjologii, (ed.) Boratyński A., Bugała W., Polska Akademia Nauk, Instytut Dendrologii, Bogucki Wydawnictwo Naukowe, Poznań. (in Polish)

ROBERTSON I., ROLFE J., SWITSUR V.R., CARTER A.H., HALL M.A., BARKER A.C., WATERHOUSE J.S. 1997. Signal strength and climate relationships in ${ }^{13} \mathrm{C} /{ }^{12} \mathrm{C}$ ratios of tree ring cellulose from oak in southwest Finland. Geophys. Res. Lett., 24, 1487-1490.

SAURER M., SIEGENTHALER U. 1989. ${ }^{13} \mathrm{C} /{ }^{12} \mathrm{C}$ isotope ratios in trees are sensitive to relative humidity. Dendrochronologia, $7,9-13$

SCHLESER G.H. 1991. Carbon isotope fractionation during $\mathrm{CO}_{2}$ fixation by plants, Modern Ecology: Basic and Applied Aspects, G. Esser \& Overdieck, Elsevier, czapt. 28, p. 603.

SCHLESER G.H. 1999. ${ }^{13} \mathrm{C} /{ }^{12} \mathrm{C}$ in growth rings and leaves: Carbon distribution in trees, Fossil Plants and Spores: modern techniques. The Geological Society, London.

SZARAN J. 1990. The $\delta^{13} \mathrm{C}$ and $\mathrm{CO}_{2}$ concentration in the air. In: Course-book on Isotope Geology, (ed.) M.O. Jędrysek, pp. 160-168, Wroclaw Univ. and Comm. Mineral. Sci.

VAN DE WATER P.K. 2002. The effect of chemical processing on the $\delta^{13} \mathrm{C}$ value of plant tissue. Geochemica and Cosmochemica Acta, Vol. 66, No. 7, pp. 1211-1219. 